\title{
Indebtedness at Household Level and Investigating the Household Financial Health- A Mixed Study on Azad Nagar and Audali Village of Udam Singh Nagar District, Uttarakhand, 2016-2017
}

\author{
Babul Hossain ${ }^{1 *}$, Mijanur Rahman ${ }^{2}$ \\ ${ }^{1}$ Masters in population studies from International Institute of Population Sciences, Mumbai \\ ${ }^{2}$ Dept. of Geography, University of Calcutta, India
}

"Corresponding Author: Babul Hossain, Masters in population studies from International Institute of Population Sciences, Mumbai

\begin{abstract}
Background: With the village economy transition, people are shifting from tenancy relation to money borrowing from local money lender to different institutional sources. In other hand, the inform job condition, low income make villagers vulnerable toward financial crisis. The study tries to see in such scenario what is the indebtedness condition by different background character for two village-Azad Nagar and Audali located in Uttarakhand in India.
\end{abstract}

Method: The present study is based on primary survey conducted for the financial year of 2015-2016. The study includes 116 HH. Debt Service Ratio (DSR) is calculated to analyse the financial crisis condition by the HH income. Multiple regression model is used to see the possible factor effecting poor DSR value. Individual perspectives are used to understand deep about the indebtedness in the HH.

Result: Azad Nagar and Audali, in both the villages schedule group are highly vulnerable toward the indebtedness condition. Co-operative society and commercial bank provide the loan. Most of the HH are associated with inform job which are insecure and low wage based. The regression model shows that high non-food expedition and low land holding are explaining poor Debt Service Ratio. It means because of these two factors $\mathrm{HH}$ are more vulnerable toward financial crisis.

Conclusion: In Azad Nagar village the Scheduled caste and in Audali village Scheduled Tribes are vulnerable toward the financial crisis as these sections of people are not having any formal job security. With expenditure related to high non-food consumption and low land holding has significant effect on the high indebtedness for both the villages and it also lead to high vulnerability to eard financial crisis.

Keywords: Indebtedness, Rural economy, Debt service ratio, Caste indebtedness, Source of loan

\section{BACKGROUND}

Indebtedness of household very much represents the household economy, their shock vulnerability in economic [1].In the rural setup in India, tenancy relation is decreasing and form of indebtedness in money term is more prevailing condition [2].As per NSSO definition Indebted household is one which has any loan outstanding on the date of survey. Loans include borrowing in cash and / or kind (including hire purchase) as well as credit purchase evaluated at local retail price prevailing in the market. In year 2013-2014, the Incidence of Indebtedness (IOI) was about 31.4\% among the rural households and 22.4\% among the urban households for India (NSS). Average amount of Debt (AOD) per indebted household was Rs. 103457 and Rs. 378238 in the rural and urban areas respectively. Over the time source of money for debt in the rural area shifted from the money lender to the institutional sources [3]. In rural, the share of debt from the institutional credit agencies was 56\% against $44 \%$ from the non-institutional credit agencies. In urban, the share of debt from the noninstitutional credit agencies was $15 \%$ compared to $85 \%$ from the institutional credit agencies. With the structural insecurity in the job market experienced by laborers has forced them to experience different informal jobs and to aspire for better conditions with increase in consumption ultimately end up with over indebtedness [4]. In other hand caste play an important role in the rural area for money borrowing. The indebtedness is associated with different social identity [5]. With the social identity, 
the possession of the materialistic asset as well as the household income can be used to explain the indebtedness condition. Studies shows that the lower HH income is directly associated with higher incidence of indebtedness cases as well as it also make the HH highly vulnerable toward economic shocks [1].NSSO $70^{\text {th }}$ round (2013) report shows that Only for Uttarakhand, incident of $\mathrm{HH}$ indebtedness near about $31.4 \%$ and average amount of debt per household is 26336 . Out of 1000 households with regular wage/salary 337 households are regular wage or salary earning and followed by self-employed in agriculture households are 324 out of 1000 . This study try to find what is the ground reality of indebted households in the villages in Uttarakhand. The study try to address the question that which section of people in villages are in indebtedness, what is the financial health of the household means how they are spending to cover their indebt with respect to their household income and which factor explain the indebtedness of the household over the villages in Udam Singh nagar district.

\section{MATERial AND MeTHOD}

\subsection{Study Area}

For the study two villages of Udamsinghnagar are selected. First one is Azad Nagar which is a resettlement village after independent (1947) of India mixed with different type of ethnic group. Second village is Audhali which is a Tharu dominating tribal village. From both the villages 116 samples is interviewed using stratified random sampling. For the village Azadnagar, it is located at the fringe area of the nearby main town Kiccha whereas the Lamakhera is nearst town of Audhali village.

\subsection{Data Source}

The study is based on primary survey data which was conducted between the first to third weeks of December, 2017. 116 samples are collected for both the villages using stratified random sampling method. Along with personal and household level interviews, Participatory Rural Appraisal (PRA), Transect walk, Focus Group Discussion (FGD) techniques are used to collect the data on different aspects. In the study data is pooled for both villages.

\subsection{Variables}

- Dependent variable: Level of indebtedness measured in term Debt Service Ratio (DSR)

- For the village profiling- HH income, interest rate, HH size, amount borrowed and other descriptive variables are considered for village wise.

- Independent variable- HH income, amount borrowed, interest rate, HH size, land owned, food expenditure, non-food expenditure is considered. The data is pooled for regression section.

\subsection{Target Population}

The study includes 116 sample HHs from both villages but only those $\mathrm{HH}$ are considered who has any loan outstanding on the date of survey

\subsection{Data Analysis Tool}

The study will follow mixed research design. For household profiling by indebtedness, different descriptive statistics is used. For the Household economic health condition- Debt Service Ratio (DSR) is used;

$$
\begin{gathered}
\text { Debt Service Ratio }(D S R)=\frac{D i}{\mathrm{Ti}} * 100 \\
\text { Where, } D I=\text { Total annual payment to serve the debt ( prinicipal + interest), } \\
\qquad i=\text { Gross annual HH income }
\end{gathered}
$$

DSR value shows the HH financial condition and how much the households are vulnerable in the indebted condition. There is no universal DSR value as benchmark to defer what will indicate a HH vulnerable or bad financial condition. DeVaney in 1994 stated $40 \%$ as a benchmark for crude DSR value where gross income is used as a denominator; in this study this value is also used. Narratives are used as qualitative analysis for study. To analyze the explanting factors leads to indebtedness among household, multiple regression model has used. Here important thing is that sample regarding to the 
indebtedness is low so to run the regression model indebted sample $\mathrm{HH}$ of both the villages are pooled. For the study the different narratives of individuals and quantitative data have also be used.

\section{RESUlT}

For the Azad Nagar village almost 22 household we find having debt and based on that the livelihood of the household head is given by their social category which shows that among HH engaged in crop production $50 \%$ are of Schedule caste(SC) and 50\% of other category (Table-1). Whereas among salaried work depend $\mathrm{HH}$ these $\mathrm{HH}$ are belong to SC category. As Audali village is dominated by Tharu tribes so in all the indebted HHs, Schedule Tribe (ST) social category is dominating. Only for the self-employed in service $\mathrm{HHs} 66.7 \%$ ST and $33.3 \%$ OBC HHs are in debt. If we go through the indebted $\mathrm{HH}$ by their $\mathrm{HH}$ income in social category, we will see for same social group the HH income varies huge. In Azan Nagar, 60\% SC HH has less than Rs. 100000 annual income, only 30\% of SC $\mathrm{HH}$ has income above Rs. 150000. Among Other backward class (OBC) 50\% indebted HH income is less than $50 \%$ whereas $50 \%$ of indebted OBC HH has income above 150000 . In this village the general category has only $10 \%$ indebted $\mathrm{HH}$ which has $10 \% \mathrm{HH}$ with less than RS.70000 annual income.

Table1: Background characteristics of Azad nagar and Audhali village, 2015-2016

\begin{tabular}{|l|l|l|l|l|l|}
\hline Village & \multicolumn{2}{l|}{ Azam Nagar } & \multicolumn{2}{l|}{ Audhali } \\
\hline Social category & SC & OBC & \multicolumn{2}{l|}{ Other/General } & \multicolumn{2}{l|}{ ST } & OBC \\
\hline Livelihood & & & & & \\
\hline Crop Pproduction & 50 & 50 & 0 & 100 & 0 \\
\hline Agricultural casual labour & 25 & 0 & 75 & 100 & 0 \\
\hline Self employed & 50 & 50 & 0 & 66.7 & 33.3 \\
\hline Permanent salaried worker & 100 & 0 & 0 & 100 & 0 \\
\hline Unemplyed & 60 & 40 & 0 & 100 & 0 \\
\hline Student & 66.6 & 33.3 & 0 & 100 & 0 \\
\hline Other & 0 & 33.3 & 66.6 & 100 & 0 \\
\hline Income & & & & & \\
\hline Less than 70000 & 30 & 50 & 10 & 35 & 100 \\
\hline $70000-100000$ & 30 & 0 & 20 & 25 & 0 \\
\hline $100000-150000$ & 10 & 0 & 20 & 25 & 0 \\
\hline More than 150000 & 30 & 50 & 50 & 15 & 0 \\
\hline
\end{tabular}

For Azad Nagar the most interesting thing is that cooperative credit societies are the single most important source of loan for small amount. Money lenders are not the source of the loan borrowed as per the amount is also very much different between the villages (Figure 1). For Audali village the high amount of loan is taken from commercial banks and along with this cooperative credit societies play important role for small $\mathrm{HH}$ credits. But one interesting thing is that friends and relatives are important source of loan in Audali village (Figure 2).

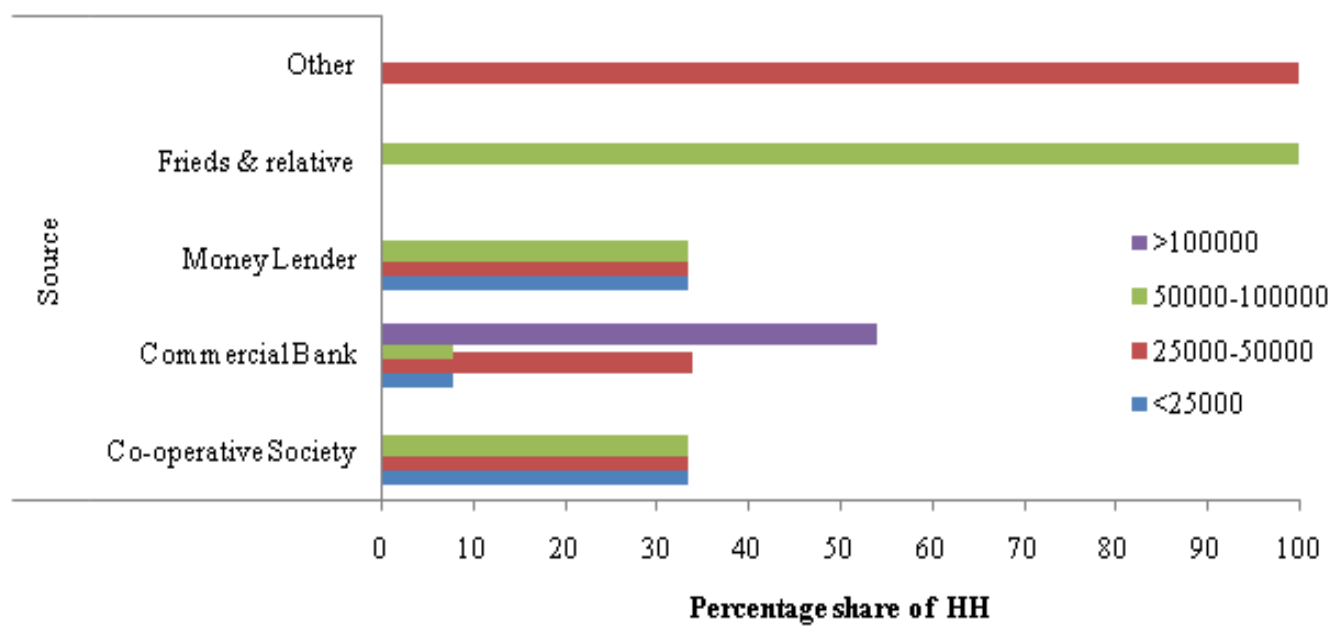

Figure1: Different Sources of money for indebted HH, Audhali 


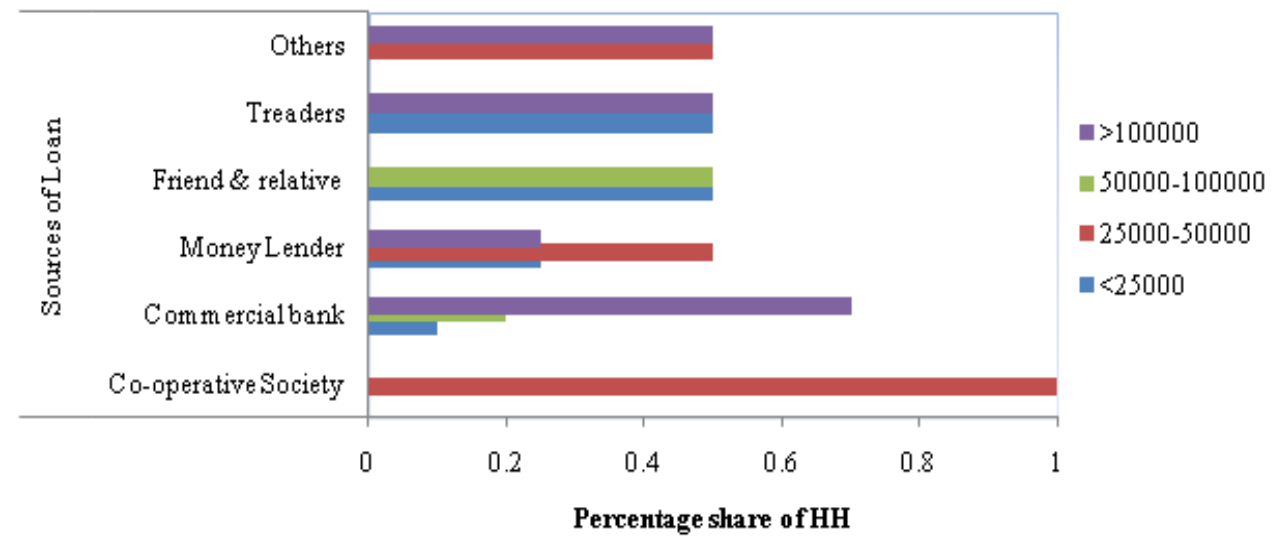

Figure2: Different Sources of money for indebted HH, Azad Nagar

\subsection{Financial Health Condition of the Indebted Household by Income}

The term financial health is used to refer the financial condition of an individual or company's status, how it deal with its income and with its expenditure. The financial health of a household tries to examine the condition between household expenditure with respect to its income (Faruqui el al., 2008). One of the determining factors of the $\mathrm{HH}$ financial health is debt and other related payment. The DSR value is appropriate in this condition to predict what a $\mathrm{HH}$ reaction toward any financial shock. Conventionally 40 is taken as a bench mark if gross house hold income is considered, the DSR value is above then the debt condition are assumed to be severely affecting the $\mathrm{HH}$. For the villages as DSR values are calculated. Table 2 shows the DSR value for both the village by income. For Audali more than more than 57\% HH group annual income less than Rs. 70000 annual has DSR value more than 40. This means that these low HH income groups in Audali are too much vulnerable to any kind of shock. So one can say that the low income HH in Audali village has quiet bad condition of financial health condition. Interestingly the High income $\mathrm{HH}$ in the Audali has low or no sensitivity toward any shock. Whereas for the Azad Nagar village 28.6\% low income households DSR value is above 40, same for Rs. 70000-10000 and more than Rs. 150000 income group.

Table2: Debt service ratio by income for Audhali and Azad nagar village, 2015-016

\begin{tabular}{|l|l|l|l|l|l|l|}
\hline Village & \multirow{2}{*}{ DSR } & \multicolumn{4}{|l|}{ Household Income } & \\
\cline { 3 - 7 } & & $<\mathbf{7 0 0 0 0}$ & $\mathbf{7 0 0 0 0 - 1 0 0 0 0 0}$ & $\mathbf{1 0 0 0 0 0 - 1 5 0 0 0 0}$ & $>\mathbf{1 5 0 0 0 0}$ & Total \\
\hline Audhali & $>40$ & 57.14 & 14.29 & 28.57 & 0 & 100 \\
\hline Azad Nagar & $>40$ & 28.57 & 28.57 & 14.29 & 28.57 & 100 \\
\hline
\end{tabular}

Now the question is why this is so concern for household financial health assessment, it reflects that a good amount of the $\mathrm{HH}$ income, they have to pay for servicing the debt for annual base and if any shock in terms of employment, economic and family take place that will make the household very vulnerable toward different financial crisis. Few of the narratives can highlight the scenario.

KartikBiswas resident of Azad nagar village said-

"With three depended for bread on him, I have to borrow for my daughter's marriage. I don't have proper permanent job to sustain family and the installment of loan make my situation more vulnerable"

Another Resident from Azad Nagar Sima Sharma, who runs a small beauty parlor said-

"My elder son is having his higher education at Mumbai and for this I have to borrow money from his education".

From Audali, Vir Singh who is cultivator said-

"For cultivation I have borrowed money from local money lender at very high interest rate and I have to pay a good piece of my income money as a interest every month" 
For Audali, a general tendency to borrow money from friend and money lender at higher interest rate is one of the reasons for vulnerability among the HHs.

\subsection{Factor Explaining the Bad Household Financial Condition among HH}

This section will try to highlight the factors affecting the high DSR value which mean poor household financial condition. To explain the High prevalence of DSR value among the $\mathrm{HH}$, regression has run. The table 3 shows that amount borrowed, non-food expenditure and amount of land is significantly relate with DSR value at 5,10 confidence level, respectively. The model says that the 1 unit change in non-food consumption will lead to 0.0409 unit change in DSR value positively whereas 1 unit change in amount of land will lead to 61.60 unit of change of DSR value negatively, in other hand one unit change in the amount of borrow money it is lead to 0.003516 unit change in DSR value positively,. Whereas other variables are not that much significant to address the change in the DSR value

Table3: Determination of factors effecting DSR values in the study area, 2015-2016

\begin{tabular}{|l|l|l|}
\hline DSR Value & Coefficient & Std. Err. \\
\hline Total HH Income & 0.03842 & 0.000236 \\
\hline Amount Borrow & $0.003516^{* *}$ & 0.0001 \\
\hline Interest rate & 29.56785 & 20.96576 \\
\hline HH size & 12.50597 & 22.20308 \\
\hline Amount of land & $-61.60456^{*}$ & 35.60823 \\
\hline Non food consumption & $0.0409555^{* *}$ & 0.018388 \\
\hline Food consumption & 0.0002571 & 0.000509 \\
\hline Constant & 52.9269 & 197.1321 \\
\hline R-square- 0.8371 & Adjust R square $=0.557$ & \\
\hline
\end{tabular}

(The regression is done using pooled data for both the sample village. The symbols * and ** indicates that the coefficients are statistically significant at 10, 5 confidence level, respectively)

\section{DisCUSSION}

In Azad Nagar poor SC unemployed peoples are highly vulnerable to the debt conditions, whereas for ST Audali the casual labour and salaried labours are exposed to indebtedness [6].In Azad Nagar, cooperative societies are one of major source of loan and for Audali along with cooperative societies peoples are borrowing money from money lender and friend-relatives at high interest rate. The study finds that like other existing study, low income groups are vulnerable toward indebtedness [1]. In Azad Nagar share of $\mathrm{HH}$ is low toward any vulnerability of any financial shock, but in Audali low income (<70000 rupees annually) HHs have very high vulnerability toward any kind of financial shock but highest income $\mathrm{HH}$ has no such vulnerability toward any financial shocks so their $\mathrm{HH}$ financial condition is quiet good compare to the low income $\mathrm{HH}$. Whereas the high presence of Debt service ratio (DSR) among the $\mathrm{HH}$ is because of the low land availability of households, increase in the non- food consumption expenditure and amount of money.

\section{CONCLUSION}

In Azad Nagar village the Scheduled caste and in Audali village Scheduled Tribes are vulnerable toward the financial crisis as these sections of people are not having any formal job security. With expenditure related to high non-food consumption and low land holding has significant effect on the high indebtedness for both the villages and it also lead to high vulnerability to eard financial crisis.

\section{REFERENCE}

[1] Faruqui, U. (2008). Indebtedness and the Household Financial Health: An Examination of the Canadian Debt Service Ratio Distribution. Bank of Canada.

[2] Bardhan, P., \&Rudra, A. (1978). Interlinkage of Land, Labour and Credit Relations: An Analysis of Village Survey Data in East India. Economic and Political Weekly, 13, 367-384. doi:10.1002/9780470752 777. ch18

[3] Ramachandra, K. S., Rao, \&Tripathi, A. K. (2001). Indebtedness of Households: Changing Characteristics. Economic and Political Weekly, 1617-1626.

[4] Purkayastha, G. (2001). Rural Indebtedness in Assam Changing Scenario. Economic and Political Weekly, 2239-2241 
[5] Guerin, I., Roesch, M., Venkata subramanian, G., \&Santosh, K. S. (2014). The social meaning of overindebtedness and creditworthiness in the context of poor rural South Indian households Tamil Nadu. Routledge Taylor \& Francis, 125-149

[6] Subha, K. G., Rao. (2006). Indebtedness of Cultivator Households Some Puzzling. Economic and Political Weekly, 3460-3463.

[7] Picherit, D. (2014). Protection and over- indebtedness in rural South India: The case of labour migrants of Andhra Pradesh. Routledge Taylor \& Francis, 151-170.

[8] Greenberg M.S. (1980) A Theory of Indebtedness. In: Gergen K.J., Greenberg M.S., Willis R.H. (eds) Social Exchange. Springer, Boston, MA

[9] DeVaney, S.A. 1994. "Usefulness of financial ratios as predictors of household insolvency."Financial Counselling and Planning, Vol. 5, 1994: 5-24.

\section{AUTHORS' BiOgRAPHY}

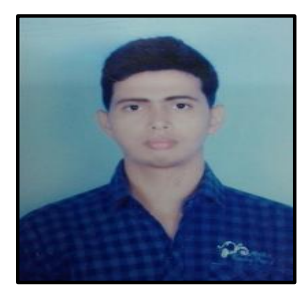

Mr. Babul Hossain, is currently an M.Phil. Student at International Institute for Population Sciences (IIPS) in the department of development studies, Mumbai. He holds a master's in Geography from Jawaharlal Nehru University, New Delhi and second master's in Population Studies from IIPS, Mumbai. His research interest include demography and development, health geography and urban policies focusing health and development, migration issues.

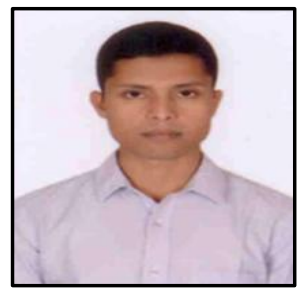

Mr. MdMijanur Rahman, is currently an Ph.D. student at Seacom Skills University (SSU),W.B in the department of education. He holds a masters in Geography from University of Calcutta, Kolkata, Secondmaster's in Education from University of Kalyani, W.B, Third masters of Education (M.Ed) from David Hare Training College, WBUTTEPA, Kolkata. His research interest include health geography, urban geography, geomorphology, inclusive education, teacher education, educational psychology, sociology of education (Education of Minority).

Citation: Babul Hossain, Mijanur Rahman. "Indebtedness at Household Level and Investigating the Household Financial Health- A Mixed Study on Azad Nagar and Audali Village of Udam Singh Nagar District, Uttarakhand, 2016-2017”. International Journal of Research in Geography. vol 5, no. 3, 2019, pp. 16. doi: http://dx.doi.org/10.20431/2454-8685.0503001.

Copyright: (c) 2019 Authors. This is an open-access article distributed under the terms of the Creative Commons Attribution License, which permits unrestricted use, distribution, and reproduction in any medium, provided the original author and source are credited. 